\title{
HUBUNGAN ANTARA RASA SYUKUR TERHADAP KESEHATAN MENTAL REMAJA DI SMA NEGERI 8 PEKANBARU
}

\author{
Rani Hardianti ${ }^{1}$, Erika ${ }^{2}$, Fathra Annis Nauli ${ }^{3}$ \\ 1,2,3 Fakultas Keperawatan Universitas Riau \\ Jalan Pattimura No 9 Gedung G Pekanbaru Riau \\ email: ranihardianti17@gmail.com
}

\begin{abstract}
Abstrak
Pentingnya menjaga kesehatan mental dapat berimbas pada kesejahteraan diri remaja. Remaja yang memiliki kesehatan mental positif terhindar dari masalah mental emosional yang bersifat neurosis maupun psikosis. Tujuan penelitian ini adalah untuk mengetahui hubungan antara rasa syukur terhadap kesehatan mental remaja SMAN 8 Pekanbaru. Pendekatan cross sectional digunakan sebagai metode penelitian. Sampel dalam penelitian ini adalah 81 orang yang diambil dengan menggunakan teknik stratified random sampling. Pengumpulan data diambil dengan menggunakan kuesioner rasa syukur dan kesehatan mental. Hasil penelitian menunjukkan bahwa terdapat hubungan yang signifikan positif rasa syukur dengan kesehatan mental remaja di SMA Negeri 8 Pekanbaru $(0,011<0,05)$. Penelitian ini merekomendasikan kepada pihak sekolah untuk terus meningkatkan kegiatan yang mendorong rasa syukur remaja sebagai upaya menjaga kesehatan mental remaja.
\end{abstract}

Kata kunci: kesehatan mental, rasa syukur, remaja

\begin{abstract}
The importance of maintaining mental health can impact on the well-being of adolescents. Adolescents who have positive mental health avoid mental emotional problems that are neurotic or psychotic. The aimed of this research was to determine the correlation between gratitude on mental health adolescents of SMAN 8 Pekanbaru. This study used a cross sectional approach. The sample in this study were 81 people taken using the stratified random sampling technique. Data collection was taken using a gratitude and mental health questionnaire. Data collection was taken using a questionnaire of gratitude and mental health. The results showed that there was a significant positive relationship between gratitude and the mental health of adolescents in SMA Negeri 8 Pekanbaru $(0,011<0,05)$. This research is useful for schools to continue to improve activities that encourage adolescent gratitude as a monitoring of adolescent mental health.
\end{abstract}

Keywords: mental health, gratitude, adolescent 
Rani Hardianti, Erika, Fathra Annis Nauli, Hubungan antara Rasa Syukur terhadap Kesehatan Mental Remaja di SMA Negeri 8 Pekanbaru

\section{PENDAHULUAN}

Kesehatan mental yaitu suatu keadaan kesejahteraan ketika seseorang menyadari keterampilannya, mampu mengatasi tekanan kehidupan yang normal, mampu berkegiatan produktif, dan dapat berkontribusi kepada komunitas dan masyarakat (WHO, 2016).

Data Riset Kesehatan Dasar menunjukkan bahwa $10,1 \%$ penduduk Indonesia dengan usia diatas 15 tahun mengalami gangguan kesehatan mental dan emosional (Riskesdas, 2018). Peraturan Kesehatan RI Nomor 25 tahun 2014, menjelaskan bahwa remaja adalah penduduk dalam rentang usia 10-18 tahun dan menurut Badan Kependudukan dan Keluarga Berencana (BKKN) rentang usia remaja adalah 10-24 tahun dan belum menikah. Menurut Statistik Pendidikan dan Kebudayaan, usia 15-18 tahun berada pada bangku Sekolah Menengah Atas (Kementerian Pendidikan dan Kebudayaan, 2016). Prevalensi gangguan mental emosional pada penduduk usia $\geq 15$ tahun di Riau adalah sebesar $8,9 \%$ yang meningkat dari 2,3\% (Riskesdas, 2018).
Pentingnya menjaga kesehatan mental dapat berimbas pada kesejahteraan diri remaja itu sendiri. Remaja yang sehat mentalnya adalah individu yang terhindar dari keluhan dan gangguan mental baik berupa neurosis maupun psikosis. Orang yang sehat mental akan senantiasa merasa aman dan bahagia dalam kondisi apapun, dan akan melakukan introspeksi atas segala hal yang dilakukannya sehingga akan mampu mengontrol dan mengendalikan dirinya sendiri (Yeli, 2012). Arus positif yang kuat pada kesehatan mental dapat mengembangkan kekuatan remaja dalam menghadapi kehidupan sehari-hari (Nasilah \& Marettih, 2015). Selain itu, temuan Tambunan dan Ediati (2016) diketahui bahwa problem emosi remaja dapat beresiko bunuh diri.

Terdapat banyak faktor yang mempengaruhi kesehatan mental diantaranya religiusitas, fisik, psikis, dan lingkungan seseorang (Primaswari, 2017). Kesepian dan penyakit mental semakin meningkat secara signifikan karena kurangnya rasa syukur yang dimiliki remaja (Caputo, 2015). Rasa syukur merupakan ciri kepribadian positif klasik dan dianggap sebagai salah satu prediktor penting 
dalam kesejahteraan (Aghababae \& Tabik, 2013).

Listiyandini et al., (2015) berpendapat bahwa rasa syukur adalah dampak moral yang dapat mendorong perilaku untuk peduli pada kesejahteraan orang lain. Rasa syukur dapat menumbuhkan optimisme, memperbaiki kualitas hidup, membentuk hubungan persahabatan yang lebih baik (Husna, 2014). Penelitian terdahulu telah menemukan bahwa rasa syukur dapat mencegah depresi dan kondisi patologis (Listiyandini et al., 2015). Seseorang yang memiliki rasa syukur tinggi akan memiliki kendali yang lebih tinggi terhadap keadaan lingkungan, perkembangan personal, memiliki tujuan hidup, dan menerima keadaan dirinya. Rasa syukur seseorang akan mendorongnya memiliki coping yang baik pada kesulitan hidup, mencari dukungan sosial dari orang lain, menginterpretasikan pengalaman dengan sudut pandang berbeda, serta memiliki rencana dalam memecahkan masalah (Listiyandini et al., 2015).

Studi pendahuluan melalui wawancara dengan guru Bimbingan Konseling (BK) di
SMAN 8 Pekanbaru mengatakan bahwa cukup banyak siswa yang mengeluhkan masalah-masalah pribadi yang berhubungan dengan emosional siswa misalnya masalah pertemanan, susahnya beradaptasi di sekolah dan menyesuaikan dengan peraturan sekolah, kelola emosi negatif seperti mood tidak stabil dan uring-uringan (gelisah), tekanan atau stres akademik akibat tingginya tuntutan belajar dari orang tua, ketatnya daya saing di kelas. Gangguan jiwa berat belum pernah dilaporkan tetapi guru BK pernah menemukan beberapa orang siswa yang melaporkan dirinya stres karena susah beradaptasi dengan teman dan terdapat siswa yang mengalami masalah tekanan akademik yang tinggi yang menyebabkan siswa gelisah sehingga jika ini dibiarkan akan berdampak pada kesehatan mental. Peneliti juga mewawancari tujuh orang siswa di Sekolah tersebut. Lima diantaranya mengakui bahwa rutinnya ibadah, mengikuti ekstrakulikuler di sekolah, menambah wawasan dan mengucapkan syukur terhadap sesuatu membuat mereka menjadi lebih berlapang dada dan bersabar dalam menghadapi masalahnya. Penelitian ini 
Rani Hardianti, Erika, Fathra Annis Nauli, Hubungan antara Rasa Syukur terhadap Kesehatan Mental Remaja di SMA Negeri 8 Pekanbaru

ditujukan untuk mengetahui hubungan antara rasa syukur terhadap kesehatan mental remaja SMAN 8 Pekanbaru.

\section{METODE PENELITIAN}

Penelitan ini dilakukan di SMAN 8 Pekanbaru yang dari bulan Januari-Juni 2019. Desain penelitian ini adalah penelitian deskriptif korelasi dengan pendekatan cross sectional. Populasi dalam penelitian ini adalah seluruh siswa kelas $\mathrm{X}$ berjumlah 432 Orang pada SMAN 8 Pekanbaru, dengan jumlah sampel 81 Orang, pemilihan sampel melalui Stratified Random Sampling. Kuesioner rasa syukur yang digunakan dimodifikasi dari Listiyandini et al., (2015) sebanyak 29 pertanyaan dan kuesioner kesehatan mental dimodifikasi dari Merino et al., (2017) yang berjumlah 39 pertanyaan.

Hasil uji validitas kuesioner rasa syukur terdiri dari 29 pernyataan menghasilkan 22 pernyataan valid ( $\left.r_{\text {hitung }} 0,361-0,749\right)>r_{\text {tabel }}$ $(0,361)$ dan hasil uji validitas kuesioner kesehatan mental terdiri dari 39 pernyataan menghasikan 39 pernyataan valid ( $\mathrm{r}_{\text {hitung }}$ 0,419-0,700) > $r_{\text {tabel }} \quad(0,361) . \quad$ Hasil uji reliabilitas rasa syukur diperoleh alpha cronbach $(0,936)$ dan hasil uji reliabilitas kesehatan mental diperoleh alpha cronbach (0,945), sehingga dapat disimpulkan kuesioner rasa syukur dan kesehatan mental dikatakan valid dan reliabel. Uji Chi-Square dilakukan sebagai uji hipotesis untuk mengetahui apakah ada hubungan antara rasa syukur dengan kesehatan mental pada remaja dengan batas kepercayaan $=0,05$.

\section{HASIL PENELITIAN}

\section{Karakteristik Responden}

Tabel 1

Karakteristik responden berdasarkan umur, jenis kelamin, dan agama

\begin{tabular}{lcc}
\hline Karakteristik & Frekuensi & Presentasi (\%) \\
responden & & \\
\hline Umur & 1 & 1,2 \\
14 Tahun & 34 & 42,0 \\
15 Tahun & 44 & 54,3 \\
16 Tahun & 2 & 2,5 \\
17 Tahun & & \\
\hline Jenis Kelamin & 27 & 33,3 \\
Laki-laki & 54 & 66,7 \\
Perempuan & & 95,1 \\
\hline Agama & 77 & 3,7 \\
Islam & 3 & 1,2 \\
Protestan & 1 & 100 \\
Katolik & 81 & \\
\hline Jumlah & & \\
\hline
\end{tabular}


Tabel 1 menunjukkan karakteristik responden berdasarkan umur terbanyak adalah berusia 16 tahun sebanyak 44 responden $(54,3 \%)$. Jenis kelamin terbanyak adalah perempuan dengan jumlah 54 responden $(66,7 \%)$ dan agama responden mayoritas adalah Islam sebanyak 77 responden $(95,1 \%)$.

Tabel 2

Gambaran frekuensi tingkat rasa syukur

\begin{tabular}{|c|c|c|}
\hline $\begin{array}{l}\text { Tingkat Rasa } \\
\text { Syukur }\end{array}$ & Frekuensi & Persentase $(\%)$ \\
\hline Tinggi & 41 & 50,6 \\
\hline Rendah & 40 & 49,4 \\
\hline Jumlah & 81 & 100 \\
\hline
\end{tabular}

Tabel 2 menunjukkan bahwa dari 81 responden, mayoritas responden memiliki tingkat rasa syukur tinggi sebanyak 41 orang $(50,6 \%)$

Tabel 3

Gambaran aspek-aspek kesehatan mental

\begin{tabular}{lcccc}
\hline $\begin{array}{c}\text { Aspek-aspek } \\
\text { Kesehatan } \\
\quad \text { Mental }\end{array}$ & \multicolumn{2}{c}{ Negatif } & \multicolumn{2}{c}{ Positif } \\
\cline { 2 - 5 } & $\mathrm{n}$ & $\%$ & $\mathrm{n}$ & $\%$ \\
\hline $\begin{array}{l}\text { Kepuasan } \\
\text { Personal }\end{array}$ & 38 & 46,9 & 43 & 53,1 \\
\hline Sikap Prososial & 37 & 45,7 & 44 & 54,3 \\
\hline Kontrol Diri & 38 & 46,9 & 43 & 53,1 \\
\hline Kemandirian & 33 & 40,7 & 48 & 59,3 \\
\hline
\end{tabular}

\begin{tabular}{lcccc}
\hline $\begin{array}{c}\text { Aspek-aspek } \\
\text { Kesehatan } \\
\text { Mental }\end{array}$ & \multicolumn{2}{c}{ Negatif } & \multicolumn{2}{c}{ Positif } \\
\cline { 2 - 5 } & $\mathrm{n}$ & $\%$ & $\mathrm{n}$ & $\%$ \\
\hline $\begin{array}{l}\text { Penyelesaian } \\
\text { masalah }\end{array}$ & 28 & 34,6 & 53 & 65,4 \\
Aktualisasi Diri & & & & \\
\hline $\begin{array}{l}\text { Kemampuan } \\
\text { hubungan }\end{array}$ & 33 & 40,7 & 48 & 59,3 \\
Interpersonal & & & & \\
\hline
\end{tabular}

Berdasarkan tabel 3 diatas diketahui bahwa 81 orang responden yang diteliti diperoleh hasil mayoritas responden memiliki penyelesaian masalah dan aktualisasi diri yang positif sebanyak 53 orang $(65,4 \%)$.

Tabel 4

Gambaran frekuensi kesehatan mental

\begin{tabular}{lcc}
\hline $\begin{array}{l}\text { Skor Kesehatan } \\
\text { Mental }\end{array}$ & Frekuensi & $\begin{array}{c}\text { Persentase } \\
(\%)\end{array}$ \\
\hline Positif & 41 & 50,6 \\
\hline Negatif & 40 & 49,4 \\
\hline Jumlah & 81 & 100 \\
\hline
\end{tabular}

Tabel 4 menggambarkan bahwa 81 responden yang diteliti didapatkan hasil mayoritas responden memiliki kesehatan mental positif sebanyak 41 orang $(50,6 \%)$. 
Rani Hardianti, Erika, Fathra Annis Nauli, Hubungan antara Rasa Syukur terhadap Kesehatan Mental Remaja di SMA Negeri 8 Pekanbaru

2. Hubungan Rasa Syukur dengan yang memiliki tingkat rasa syukur yang

\section{Kesehatan Mental pada Remaja}

Tabel 5

Hubungan rasa syukur dengan kesehatan mental pada remaja

\begin{tabular}{|c|c|c|c|c|c|}
\hline Rasa & \multicolumn{2}{|c|}{ Kesehatan Mental } & \multirow{3}{*}{ Total } & \multirow{2}{*}{$\begin{array}{l}\text { OR } \\
(95 \%\end{array}$} & \multirow[b]{2}{*}{$p$} \\
\hline Syukur & Negatif & Positif & & & \\
\hline & & & & CI) & value \\
\hline \multirow[t]{2}{*}{ Rendah } & 26 & 14 & 40 & \multirow{4}{*}{$\begin{array}{r}3,582 \\
1,433- \\
8,950\end{array}$} & \multirow{6}{*}{0,011} \\
\hline & $(32,1 \%)$ & $(17,3 \%)$ & $(51,9 \%)$ & & \\
\hline \multirow[t]{2}{*}{ Tinggi } & 14 & 27 & 41 & & \\
\hline & $(17,3 \%)$ & $(33,3 \%)$ & $(48,1 \%)$ & & \\
\hline \multirow[t]{2}{*}{ Total } & 40 & 41 & 81 & & \\
\hline & $(49,4 \%)$ & $(50,6 \%)$ & $(100 \%)$ & & \\
\hline
\end{tabular}

Hasil analisis hubungan rasa syukur dengan

kesehatan mental pada remaja didapatkan hasil

bahwa dari 81 responden yang di teliti lebih banyak yang memiliki rasa syukur yang tinggi dan kesehatan mental yang positif sebanyak 27 orang (33,3\%). Hasil uji statistik menggunakan uji Chi-Square, didapatkan $p$ value $0,011<\alpha(0,05)$, disimpulkan Ho ditolak dan $\mathrm{Ha}$ diterima, menunjukkan adanya hubungan antara rasa syukur dengan kesehatan mental pada remaja. Hasil analisis diperoleh nilai $\mathrm{OR}=3,582$, artinya dapat dikatakan bahwa responden yang memiliki tingkat rasa syukur yang tinggi cenderung berpeluang memiliki kesehatan mental yang positif sebesar 3,58 kali lebih besar dari responden rendah.

\section{PEMBAHASAN}

\section{Analisis Univariat}

\section{a. Umur}

Penelitian yang melibatkan 81 responden diperoleh hasil bahwa umur responden terbanyak yaitu berumur 16 tahun sebanyak 44 responden $(54,3 \%)$, dimana dengan rentang usia 14-16 tahun maka responden dapat dikategorikan sebagai remaja. Putro (2017) berpendapat bahwa proses perkembangan pada remaja yang meliputi perubahan seperti pada perkembangan psikoseksual, hubungan dengan orangtua dan cita-cita. Chabbra dan Sodhi (2011) juga menemukan bahwa masalah psikologis secara signifikan lebih tinggi pada remaja pertengahan (14-16 tahun).

\section{b. Jenis Kelamin}

Karakteristik reponden berdasarkan jenis kelamin yang diteliti terhadap 81 responden diperoleh mayoritas responden perempuan berjumlah 54 orang $(66,7 \%)$. Sughayr dan Ferwana (2012) mengatakan bahwa anak perempuan lebih stres daripada laki-laki. Wuon, Bidjuni dan Kallo (2016) berpendapat 
bahwa depresi sering terjadi pada perempuan hal ini dikarenakan perempuan mengedepankan perasaan emosional sehingga cepat merasa bersalah dan memiliki kecemasan yang cenderung tinggi daripada laki-laki.

\section{c. Agama}

Hasil penelitian sebagian besar pendidikan terakhir responden SMA sebanyak 46 orang $(31,9 \%)$. Hasil penelitian didapatkan bahwa mayoritas agama responden adalah Islam dengan 77 responden $(95,1 \%)$. Dalam setiap agama selalu mengajarkan hal baik kepada setiap penganutnya, seperti halnya setiap manusia dianjurkan untuk selalu bersyukur atas apa yang dimiliki. Pemahaman agama yang baik akan menumbuhkan perilaku yang baik. Hal ini dikarenakan remaja memerlukan kemampuan pemecahan masalah yang baik, sehingga remaja mampu menyelesaikan masalah mereka dengan efektif. Hal ini dikarenakan Agama Islam adalah agama yang memiliki konsep rasa syukur yang tertuang dalam rasa sabar dan menerima (Haryanto \& Kertamuda, 2016).

\section{d. Gambaran Rasa Syukur Responden}

Hasil penelitian yang telah dilakukan pada 81 responden diperoleh hasil mayoritas responden memiliki rasa syukur tinggi berjumlah 41 orang $(50,6 \%)$, sehingga dapat dikatakan bahwa mayoritas responden memiliki perilaku yang cukup baik dalam memperhatikan dan menghargai kepositifan dalam hidup. Sesuai dengan teori Wood, Froh dan Graghty, (2010), berpendapat bahwa rasa syukur terlihat dari karakter dan orientasi hidup terhadap pembentukan dan penghargaan pada hal-hal positif.

Listiyandini et al., (2015) juga mengemukakan bahwa orang yang memiliki rasa syukur memiliki ciri-ciri seperti tidak merasa kekurangan dalam hidupnya, memiliki kecenderungan untuk menghargai dan merasakan kesenangan yang sederhana (simple pleasure). Orang yang selalu merasakan rasa syukur terhadap setiap apa yang terjadi dalam hidupnya akan selalu merasakan hal positif, yang juga dapat mempengaruhi jiwa, mental, hati dan pikiran tetap terjaga kondisinya.

Rasa syukur merupakan proses yang berorientasi pada perilaku prososial (Petrocchi 
Rani Hardianti, Erika, Fathra Annis Nauli, Hubungan antara Rasa Syukur terhadap Kesehatan Mental Remaja di SMA Negeri 8 Pekanbaru

\& Couyoumdjian, 2016). Rasa syukur berbelas kasih dan meyakinkan diri mereka memungkinkan seseorang untuk memperkuat ikatan sosial dan persahabatan dengan adanya kepuasan hubungan (Armenta, Fritz \& Lyubomirsky, 2016), dan hal ini mendorong seseorang untuk terlibat dalam perilaku pemeliharaan hubungan yang lebih baik (Lambert \& Fincham, 2011).

Rasa syukur juga dikaitkan dengan hubungan yang membaik dengan diri, dalam bentuk cara perawatan yang lebih positif dan berbelas kasih terhadap diri sendiri ketika ada yang salah dalam hidup, sehingga menjadikan orang yang memiliki rasa syukur tinggi cenderung kurang tertekan dan cemas. Dapat dikatakan bahwa orang yang memiliki rasa syukur yang tinggi dapat menjadikan seorang tersebut memiliki pelindung terhadap rasa depresi dan cemas karena rasa syukur terhubung dengan perasaan yang baik dan rendah hati. Rasa syukur merupakan mediator yang jauh lebih kuat dalam meningkatkan kepercayan diri, dengan demikian, orang yang memiliki rasa syukur yang tinggi cenderung mengalami lebih sedikit kecemasan terutama karena mereka mampu mendorong diri, sendiri ketika ada yang salah dalam hidup (Petrocchi \& Couyoumdjian, 2016).

\section{e. Gambaran Kesehatan Mental}

Hasil penelitian yang telah dilakukan pada 81 responden diperoleh hasil bahwa mayoritas remaja memiliki kesehatan mental positif diperoleh sebanyak 41 orang $(50,6 \%)$, sehingga dapat dikatakan mayoritas responden memiliki atau menyadari keterampilannya dan mampu mengatasi tekanan kehidupan yang normal, seperti definisi dari WHO (2016) bahwa kesehatan mental yaitu suatu keadaan kesejahteraan di mana individu menyadari keterampilannya, mampu mengatasi tekanan kehidupan yang normal, dapat bekerja secara produktif, dan mampu memberikan kontribusi kepada komunitas dan masyarakat. Karaktertistik orang yang memiliki mental sehat adalah terhindar dari gejala-gejala gangguan jiwa dan penyakit jiwa, dapat menyesuaikan diri, mengembangkan potensi semaksimal mungkin, tercapai kebahagiaan pribadi dan orang lain (Yusuf, 2018).

Kesehatan mental dapat berupa berbagai gejala, diantaranya kecemasan (ansietas), 
depresi yang dapat digambarkan dari kehilangan semangat, mengalami gangguan tidur, hingga ide untuk menyakiti diri sendiri bahkan hingga timbulnya keinginan untuk bunuh diri. (Maulana, Elita \& Misrawati, 2015). Remaja merupakan periode kritis perkembangan anak menjadi dewasa, pada saat ini terjadi perkembangan hormonal, fisik, psikologis dan sosial yang cepat. Macam-macam perubahan perilaku remaja sering menyebabkan konflik antara lingkup pergaulan dan dirinya sendiri sehingga terjadi konflik internal maupun eksternal. Remaja yang tidak memiliki coping yang baik cenderung memiliki permasalahan yang bersifat negatif dan akan berimbas pada perkembangannya, misalnya pada pematangan karakter dan hal inilah yang menjadi pemicu gangguan terhadap kesehatan mental.

Emosi yang tidak stabil juga akan berdampak pada pergaulan remaja. Teman sebaya ataupun orang lain akan sulit memahami apa yang dirasakan remaja tersebut (Maulana, Elita \& Misrawati, 2015).

Pada masa remaja juga terjadi adanya tekanan akademik yang dapat menyebabkan penurunan kesehatan mental. Jayanthi,

Thirunavukarasu dan Rajkumar

menemukan bahwa remaja dengan stres akademik memiliki risiko depresi lebih tinggi daripada remaja tanpa stres akademik.

\section{Hubungan Rasa Syukur dengan \\ Kesehatan Mental pada Remaja}

Analisis bivariat dilakukan untuk melihat hubungan rasa syukur dengan kesehatan mental pada remaja. Berdasarkan data yang di olah dengan program statistik komputer menggunakan uji Chi-Square didapatkan didapatkan $\mathrm{p}$ value $0,011<\alpha(0,05)$, dimana hasil dapat dikatakan bermakna sehingga Ho ditolak dan Ha diterima, menunjukkan adanya hubungan antara rasa syukur dengan kesehatan mental pada remaja.

Hasil penelitian yang telah dilakukan pada 81 responden diperoleh hasil yaitu $26(32,1 \%)$ responden remaja yang memiliki rasa syukur yang rendah juga memiliki kesehatan mental yang negatif dan $27(33,3 \%)$ responden remaja yang memiliki rasa syukur yang tinggi juga memiliki kesehatan mental yang positif. Analisis yang menunjukkan responden dengan rasa syukur rendah namun memiliki kesehatan 
Rani Hardianti, Erika, Fathra Annis Nauli, Hubungan antara Rasa Syukur terhadap Kesehatan Mental Remaja di SMA Negeri 8 Pekanbaru

mental yang positif berjumlah $14(17,3 \%)$ dan

responden dengan rasa syukur tinggi namun memiliki kesehatan mental yang negatif berjumlah $14(17,3 \%)$. Ini dapat diartikan bahwa rasa syukur juga dapat mempengaruhi kesehatan mental pada remaja.

Hasil penelitian ini sejalan dengan penelitian yang dilakukan oleh Aghababaei dan Tabik (2013) dengan hasil penelitian yang menunjukkan bahwa rasa syukur memiliki korelasi negatif sedang sampai kuat dengan penyakit mental dan korelasi positif dengan kesejahteraan subjektif. penelitian menunjukkan bahwa rasa syukur religius dalam kaitannya dengan kesehatan mental dan kesejahteraan subyektif. Ini menunjukkan bahwa orang yang bersyukur dan memiliki religiustitas agama yang baik memiliki efek terhadap kesehatan mental. Penelitian ini, memberikan konfirmasi lintas budaya untuk kesimpulan bahwa rasa syukur dapat mempengaruhi kesehatan mental dan fungsi positif diri, dan data ini mendukung hipotesis lebih lanjut dan lebih spesifik bahwa efek tersebut disebabkan oleh rasa syukur yang dimiliki seseorang.
Penelitian ini juga sesuai dengan teori Listiyandini dkk, (2015) yang mengatakan bahwa orang yang memiliki rasa syukur memiliki ciri-ciri seperti tidak merasa kekurangan dalam hidupnya, memiliki kecenderungan untuk menghargai dan merasakan kesenangan yang sederhana (simple pleasure). Orang yang selalu merasakan rasa syukur terhadap setiap apa yang terjadi dalam hidupnya akan selalu merasakan hal positif, yang juga dapat mempengaruhi jiwa, mental, hati dan pikiran tetap terjaga kondisinya.

Rasa syukur dapat menumbuhkan optimisme, memperbaiki kualitas hidup, membentuk hubungan persahabatan yang lebih baik kepada orang lain yang berada disekitarnya yang dimana hubungan dengan orang lain dapat mempengaruhi tingkah laku, pemikiran dan suasana hati (Husna, 2014). Rasa syukur tinggi akan menyebabkan seseorang memiliki coping yang baik dalam menghadapi permasalahan dalam hidup. Rasa syukur mendorong seseorang untuk mencari dukungan sosial dari orang lain serta memahami pengalaman dari sudut pandang berbeda, sehingga membantu remaja untuk 
menyusun rencana untuk memecahkan masalah (Listiyandini, 2015). Remaja yang memiliki rasa syukur tinggi cenderung memiliki kontrol diri yang lebih tinggi terhadap lingkungan pergaulan, perkembangan personal, tujuan hidup, dan memiliki penerimaan diri yang baik sehingga berdampak pada tingkat kesehatan mental remaja tersebut.

Petrocchi dan Couyoumdjian (2016) mengatakan bahwa orang yang memiliki rasa syukur merupakan faktor pelindung terhadap kesehatan mental karena secara signifikan rasa syukur terhubung ketingkat yang lebih rendah dari perasaan tidak mampu dan rasa percaya diri. Rasa syukur juga cenderung memperlihatkan seseorang memiliki kebaikan, pemahaman, dukungan dan kasih sayang terhadap diri mereka sendri disaat mereka mengalami frustasi dan kemunduran dalam kehidupan. Rasa syukkur merupakan mediator yang jauh lebih kuat dalam meningkatkan kesehatan mental. Dengan demikian, orang yang memiliki rasa syukur yang tinggi cenderung mengalami lebih sedikit kecemasan dan memiliki kesehatan mental positif terutama karena mereka mampu mendorong dan berbelas kasih dan meyakinkan diri mereka sendiri ketika ada yang salah dalam hidupnya.

Rosmarin et al. (2011) menemukan adanya hubungan antara rasa syukur agama dan kesehatan mental dapat dimoderasi oleh keterlibatan agama. Rasa syukur yang hadir dalam wujud religiusitas maupun rasa syukur secara umum adalah penting untuk kesehatan mental dan kesejahteraan.

\section{SIMPULAN}

Hasil penelitian yang dilakukan tentang hubungan rasa syukur dengan kesehatan mental remaja di SMAN 8 Pekanbaru dengan jumlah sampel sebanyak 81 responden, diperoleh simpulan bahwa mayoritas responden berusia 16 tahun $(54,3 \%)$, jenis kelamin terbanyak adalah perempuan $(66,7 \%)$. Mayoritas beragama Islam (95,1\%).

Gambaran tingkat rasa syukur responden adalah memiliki tingkat rasa syukur tinggi $(50,6 \%)$. Gambaran kesehatan mental remaja adalah memiliki kesehatan mental tinggi 41 orang (50,6\%). Berdasarkan uji statistik 
Rani Hardianti, Erika, Fathra Annis Nauli, Hubungan antara Rasa Syukur terhadap Kesehatan Mental Remaja di SMA Negeri 8 Pekanbaru

didapatkan $\mathrm{p}$ value kurang dari nilai alpha $(0,011<0,05)$. Hal ini menunjukkan Ho ditolak sedangkan Ha diterima dan dapat disimpulkan bahwa adanya hubungan antara rasa syukur dengan kesehatan mental pada remaja. di SMAN 8 Pekanbaru.

\section{SARAN}

Hasil penelitian ini diharapkan dapat dijadikan rekomendasi bagi sekolah untuk mendukung terjaganya kesehtan mental pada remaja usia Sekolah Menengah Atas dengan memberikan pengetahuan, wawasan dan sikap yang dapat meningkatkan rasa syukur dalam proses pembelajaran agar dapat meningkatkan kesehatan mental remaja.

\section{DAFTAR PUSTAKA}

Aghababaei, N., \& Tabik, M. T. (2013) Gratitude and mental health: differences between religious and general gratitude in a Muslim context, mental health, Religion \& Culture. 16 (8), 761-766

Armenta, C. N., Fritz, M. M., \& Lyubomirsky, S. (2016). Functions of positive emotions: gratitude as a motivator of self-improvement and positive change. Emotion Review. 1 (8). DOI: $10.1177 / 1754073916669596$

Caputo, A. (2015). The relationship between gratitude and loneliness: the potential benefits of gratitude for promoting social bonds. Europe's Journal of Psychology. 11 (2), 323-334

Chhabra, G. S., \& Sodhi, M. K. (2011). Factors contributing to psychosocial ill health in male adolescents. Online Journal of Health and Allied Sciences, 10, (3), pp. $1-4$

Haryanto, H.C \& F.E Kertamuda. (2016). Syukur sebagai sebuah pemaknaan. Insight. 18 (2), 1-10

Husna \& Nurihsan, J. (2014). Landasan bimbingan dan konseling. Bandung: PT. Remaja Rosda Karya.

Jayanthi, P., Thirunavukarasu, M., \& Rajkumar, R. (2015). Academic stress and depression among adolescents: a cross-sectional. Indian Pediatrics, 52, p-271-219.

Kementerian Pendidikan dan Kebudayaan. (2016). Statistik Sekolah Menengah Atas (SMA) 2015/2016. Jakarta: Kemendikbud

Lambert, N. M., \& Fincham, F. D. (2011). Expressing gratitude to a partner leads to more relationship maintenance behavior. Emotion, 11, 52-60.

Listiyandini, R. A., Nathania, A., Syahniar, D., Sonia, L., \& Nadya, R. (2015). Mengukur rasa syukur: pengembangan awal skala bersykur versi Indonesia. Jurnal Psikologi Ulayat. 2 (2), 473-496. Merino, J. R, et.al. (2017). Reliability and validity of the positive mental health questionnaire in a sample of spanish university student. Journal of Psyciatric and Mental Health Nursing. 24 (2)

Maulana, R., Elita, V., \& Misrawati. (2015). Pengaruh murotal Al qur'an 
terhadap kecemasan pasien pre operasi bedah orthopedic. JOM, 2(2), Oktober 2015

Nasilah, S., \& Marettih, A. K. E. (2015) Integrasi diri sebagai konsep sehat mental orang melayu Riau. Jurnal Psikologi. 11 (1).

Peraturan Kesehatan RI Nomor 25 tahun 2014 tentang Upaya Kesehatan Anak Jakarta, Menteri Kesehatan Republik Indonesia.

Petrocchi, N., \& Couyoumdjia, A. (2016). The impact of gratitude on depression and anxiety: the mediating role of criticizing, attacking, and reassuring the self, Self and Identity. Journal of Self and Identity. 15 (2), 191-205

Primaswari, M. (2017). Perbedaan kualitas tidur dan kesehatan mental pada perokok dan bukan perokok. Jurnal Psikologi Universitas Muhammadiyah Surakarta. $12(1), 1-15$

Putro, K. Z. (2017). Memahami ciri dan tugas perkembangan masa remaja. APLIKASIA: Jurnal Aplikasi Ilmu-ilmu Agama. 17 (1), 25-32.

Ranasinghe, S., \& Ramesh, S. (2016). Hygiene and mental health among middle school students. India Journal of Infection and Public Health. 9 (1).

Riskesdas. (2018). Riset Kesehatan Dasar. Badan Penelitian dan Pengembangan Kesehatan, Kementerian Kesehatan RI

Rosmarin, D. H., Pirutinsky, S., Cohen, A. B., Galler, Y., \& Krumrei, E. J. (2011). Grateful to god or just plain grateful? a comparison of religious and general gratitude. The Journal of Positive Psychology, 6, 389-396.

Tambunan, Y. G. T., \& Ediati, A. (2016).
Problem emosi remaja ditinjau dari pola asuh orang tua: studi komparasi pada Siswa Parulian 1 Medan. Jurnal Empati Fakultas Psikologi UNDIP, Vol. 5 (2)

WHO. (2016). Mental Health: Strengthening Our Response. World Health Organization Diunduh dari http://www.who.int/mediacentre/factshee ts /fs220/en/. Diakses tanggal 20 Oktober 2018

Wood, A.M., Froh, J. J., Geraghty, A. W. A. (2010). Gratitude and well-being: A review and theoretical integration. Clinical Psychology Review. doi:10.1016/j.cpr.2010.03.005

Wuon, A.S, H. Bidjuni \& V. Kallo. (2016). Perbedaan tingkat depresi pada remaja yang tinggal di rumah dan yang tinggal di Panti Asuhan Bakti Mulia Karombasan Kecamatan Wanea Manado. Ejournal keperawatan. 4 (2), 1-8

Yeli, S. (2012). Psikologi agama. Pekanbaru: Zanafa Publishing.

Yusuf, S. (2018). Kesehatan mental perspektif psikologi dan agama. Bandung: Remaja Rosdakarya 